\title{
8 . The media regulation debate in a democracy lacking a free expression guarantee
}

\section{ABSTIRACII}

Two major inquiries into the Australian news media in 2011 and 2012 prompted a necessary debate over the extent to which rapidly converging and globalised news businesses and platforms require statutory regulation at a national level. Three regulatory models emerged-a News Media Council backed by recourse to the contempt powers of courts; a super self-regulatory body with legislative incentives to join; and the status quo with a strengthened Australian Press Council policing both print and online media. This article reviews the proposals and explores further the suggestion that consumer laws could be better utilised in any reform. It concludes with an assessment of the impact of the inquiries and their recommendations upon free expression in a Western democracy lacking constitutional protection of the media.

Keywords: media regulation, Australia, consumer laws, Independent Media Inquiry, Convergence Review

\section{MARK PEARSON}

Bond University, Australia

7 HIS ARTICLE reviews the major proposals for an overhaul of Australia's news media regulatory framework emanating from two pub-

lic inquiries in 2011 and 2012. It then examines the suggestion that consumer and privacy laws play a stronger role in the regulatory mix before considering the dynamics of stronger media regulation in a democracy lacking explicit constitutional protection of free expression.

The \$2.7 million Convergence Review, announced in late 2010, was meant to map out the future of media regulation in the digital era (Conroy, 2010). However, revelations of the UK phone hacking scandal and Labor and Green 
disaffection with Rupert Murdoch's News Limited in Australia, prompted the announcement in September 2011 of a subsidiary inquiry - the $\$ 1.2$ million Independent Media Inquiry — specifically briefed to deal with the selfregulation of print media ethics. Its architects - former Federal Court judge Ray Finkelstein assisted by University of Canberra journalism professor Matthew Ricketson - argued they could not decouple print news self-regulation from broadcast 'co-regulation' in the digital era, so devised a statutory model including both in their report of 28 February 2012, two months prior to the release of the report of its parent Convergence Review (Finkelstein, 2012).

\section{The Finkelstein model}

The Independent Media Inquiry report was an impressive distillation of legal, philosophical and media scholarship_compulsory reading for journalism students. Among many sensible proposals, it called for simpler codes of practice and more sensitivity to the needs of the vulnerable. But its core recommendation for the 'enforced self-regulation' of ethical standards prompted fierce debate.

It proposed a News Media Council to take over from the existing selfregulatory Australian Press Council and co-regulatory Australian Communications and Media Authority to set journalistic standards with a streamlined complaints system with teeth (Finkelstein, 2012, pp. 8-9). The body would cover print, online, radio and television standards and complaints. It would have a full-time independent chair (a retired judge or 'eminent lawyer') and 20 part-time members evenly representing the media and the general citizenry, appointed by an independent committee (Finkelstein, 2012, pp. 290-291). The government's role would be limited to securing the body's funding and ensuring its decisions were enforced, but 'the establishment of a council is not about increasing the power of government or about imposing some form of censorship' (Finkelstein, 2012, p. 9).

The report stressed the model would be 'enforced self-regulation' rather than 'full government regulation':

....an independent system of regulation that allows the regulated parties to participate in the setting and enforcement of standards (as is presently the case), but with participation being required, rather than voluntary. (Finkelstein, 2012, p. 287) 
Nevertheless, refusal to obey an order to correct or apologise would see a media outlet referred to a court which could issue an order to comply with further refusal - triggering a contempt charge and fines or jail terms for recalcitrant publishers (Finkelstein, 2012, p. 298). Such a court would be charged with the relatively straightforward task of determining whether the publisher had disobeyed an order of the statutory News Media Council. Only then might publishers get the opportunity for an appeal - again by a judge in court:

11.78 In order to preserve the ability of the News Media Council to act swiftly, there should be no internal appeal from, or internal merits review of, a determination. Nor should there be external merits review via the Administrative Appeals Tribunal.

11.79 It would, however, be neither desirable nor possible to preclude all judicial supervision of determinations. In any event, because enforcement may need to be by way of court order, judicial supervision would be built into the process. In the course of enforcement proceedings a collateral challenge to a determination may be available and this would provide a sufficient mechanism for judicial supervision. (Finkelstein, 2012, p. 299)

\section{Convergence Review report}

The 'Finkelstein inquiry' was only ever meant to be an advisory to its parent Convergence Review, chaired by former IBM Australia managing director Glen Boreham, which released its final report in April, 2012 (Convergence Review, 2012). News media regulation represented a much smaller element of the Convergence Review's overall brief, particularly after this topic had been hived off to the Finkelstein inquiry, so this matter constituted a relatively small part of its report. While the Convergence Review report shared Finkelstein's concerns about shortcomings with existing regulatory systems, it proposed that 'direct statutory mechanisms ... be considered only after the industry has been given the full opportunity to develop and enforce an effective, cross-platform self-regulatory scheme'. In other words, it was offering the media industry 'drinks at the last chance saloon' for a three-year period under its model (Convergence Review, 2012, p. 53).

Its mechanism centred upon the establishment of a "news standards body' operating across all media platforms - reinforcing the overall review's preference for 'platform neutrality' (Convergence Review, 2012, p.51). The 
news standards body 'would administer a self-regulatory media code aimed at promoting standards, adjudicating complaints, and providing timely remedies' (Convergence Review, 2012, p. 153).

Unlike Finkelstein, the Convergence Review decided not to be prescriptive about the constitution or operational requirements for such a body, beyond some broad requirements. The largest news media providers - those it deemed 'content service providers' - would be required by legislation to become members of a standards body. Most funding for the new body should come from industry, while taxpayer funds might be drawn upon to meet shortfalls or special projects (Convergence Review, 2012, p. xiv). It would feature:

- a board of directors, with a majority independent from the members;

- $\quad$ establishment of standards for news and commentary, with specific requirements for fairness and accuracy;

- implementation and maintenance of an 'efficient and effective' complaints handling system;

- a range of remedies and sanctions, including the requirement that findings be published on the respective platform. (Convergence Review, 2012, p. 51)

The review's definition of 'content service enterprises' (control over their content, a large number of Australian users, and a high level of revenue drawn from Australia) would catch about 15 media operators in its net. Others might be encouraged to join the body with a threat to remove their current news media exemptions to privacy laws and consumer law 'misleading and deceptive conduct' provisions.

While this was a novel and innovative proposal, the review only dealt with this mechanism as a hypothetical, referring readers in a footnote to pages 127 136 of the Independent Media Inquiry report for extended explanation of the exemptions. The review offered just a single sentence by way of explanation:

In particular, it seems reasonable that only those organisations that have committed to an industry self-regulatory scheme for upholding journalistic standards of fairness and accuracy should be entitled to the exemptions from the provisions of the Competition and Consumer Act 2010 concerning misleading and deceptive statements and from the obligations of the Privacy Act 1988 that would otherwise apply to those organisations. (Convergence Review, 2012, p. 51) 
There have been legislative precedents on the use of regulatory codes as a backdrop to such a provision. For example, in the UK s12(4)(b) of the Human Rights Act directs a court to take into account 'any relevant privacy code' when considering whether free expression rights should outweigh privacy rights in a given situation.

We will examine both the consumer law and privacy proposals in more detail below.

\section{The strengthened Press Council model}

Both inquiries acknowledged - and rejected - the notion of a revamped Australian Press Council proposed in various submissions and appearances by its chair, Professor Julian Disney. Nevertheless, during and after the reports, and with new support from most of its members, the Press Council moved quickly to ramp up its purview and powers to address many of its documented shortcomings (Simpson, 2012).

It locked its members into four year commitments and established an independent panel to advise on its review of its content standards. However, in its bid to extract these concessions from the owners, the council suffered the embarrassment of the exit of Seven West Media from its fold and the West Australian group then announced its own self-regulatory process (Day, 2012). Nevertheless, the council seemed poised to apply its new standards and complaints processes to all media if broadcasters and online providers decide it offers the simplest vehicle for meeting the bulk of the Convergence Review's recommendations. Either way, while the status quo remained and politicians procrastinated over whether to move to a statutory model, the Press Council could at least argue that newspaper and online news readers were being serviced by a superior complaints handling system than that which existed before the inquiries.

\section{Consumer and privacy law solutions}

The Convergence Review report cleverly proposed the removal of some existing protections instead of the imposition of draconian new regulations, but then failed to flesh out their possibilities. It needed to position its mechanism of privacy and consumer law exemptions for signatories to its new panmedia self-regulatory body as much more than hypothetical and to detail its plans for the implementation of these proposals. 
Australia already has one statutory regulator with powers to punish ethical transgressions - the Australian Competition and Consumer Commission (ACCC). In an era of increasingly commercialised and converged media, it seems reasonable that at least some forms of irresponsible journalism might be addressed via the legislative mechanism prohibiting misleading and deceptive conduct by any corporation against media consumers.

Such a legislative solution already exists, as identified by the Convergence Review - and it only requires an amendment to the existing news organisation immunity from prosecution under the 'misleading and deceptive conduct' provisions at Section 18 of the Competition and Consumer Act 2010. The proposal to take away media exemptions from prosecution under this section would leave them accountable for misleading and deceptive claims and behaviour in their editorial functions.

While misleading and deceptive conduct does not take in all unethical behaviour by news organisations or the journalists who act as their agents, it could well be read to cover such sins as lies, inaccuracy, subterfuge, and lack of verification of the false claims of others. The amendment would mean both the ACCC (and private citizens) could launch prosecutions over such behaviour, with the force of the regulatory powers it already holds. The key to this would be an amendment of the 'prescribed information provider' exception (Section 19) so that news organisations would no longer have the blanket, almost unchallengeable protection for misleading and deceptive conduct which was introduced after their lobbying in the late 1970s and early 1980s. They would only earn this exemption if they were signatories to the new self-regulatory body and abiding by its requirements.

I have previously backgrounded this news media exemption to consumer law provisions under the predecessor to the existing legislation, the Trade Practices Act 1974 (Pearson, 2000). The media operated for more than a decade under that law without special exemptions from its misleading and deceptive conduct provisions. In 1984, Section 52 (the 'misleading and deceptive conduct' clause under the TPA) caused concern in the case of Global Sportsman v. Mirror Newspapers (1984) 2 FCR 82 when it was held that the publication of statements - including statements of opinion made in the ordinary course of news - could constitute conduct which was 'misleading or deceptive'.

Successful lobbying by the media led to the government of the day introducing the exemption from the provision for 'prescribed information providers' 
unless the deception occurred in relation to the publication of advertisements or in articles promoting the information providers' own commercial interests. 'Prescribed information providers' included '... a person who carries on a business of providing information' and included obviously newspapers, holders of broadcasting licences, the Australian Broadcasting Corporation (ABC) and the Special Broadcasting Service Corporation (SBS).

The exemption — known as the 'media safe harbour' — acknowledged the fact that news organisations could not vouch for every claim made by those quoted in their news columns or stories (Applegarth, 2008). However, the instant news material was sponsored, or run in return for some compensation in cash or kind, or was used to promote the news organisation's own operations (such as in a promo), it fell within the Act and left any misleading content open to prosecution of the media proprietor.

This rendered journalists and their organisations particularly vulnerable in the realm of advertorials, if it could be shown that space had been devoted to the promotion of a company's products or services just because they happened to be advertising or they had reached some arrangement or understanding with some corporation to that effect.

If such claims were proven to be misleading or deceptive the media outlet was held responsible and could face an injunction preventing publication or a damages claim from those adversely affected.

The provision raised serious questions about media companies' crosspromotion of their related corporate interests, particularly in an age where concentrated conglomerates had substantial shareholdings and sponsorships across industries. The exemption has been struck down by superior courts in two recent cases. The High Court found against a media organisation under the former Trade Practices Act in ACCC v. Channel Seven Brisbane Pty Ltd [2009] HCA 19. That decision related to false claims on the tabloid television current affairs programme Today Tonight about goods and services. The reform would extend this to other ethical breaches. The NSW Court of Appeal had earlier ruled in TCN Channel Nine Pty Ltd v Ilvarity Pty Ltd [2008] that Nine's A Current Affair did not qualify for the exemption over misleading claims made by their staff who posed as prospective customers in an exposé of a home construction company. Their false claims were made in the course of their investigation - not while carrying on the business of providing information - and they had failed to reveal that they were in the information provision 
business during their inquiry. As Justice Applegarth has noted: 'Statements made in the course of an investigation are said to lack such correspondence because they do not occur "in the course of carrying on" a business of providing information' (2008, p. 3).

Of course, the consumer laws apply to corporations rather than individuals, so journalists themselves would not be liable personally, well exemplified in the Current Affair case cited above. However, it is likely their employer organisations would pressure them to comply when faced with the prospect of ACCC prosecutions and contempt charges for disobeying any resulting orders.

\section{Privacy solution}

The Convergence Review's suggestion that a similar 'carrot' be applied to the exemptions to privacy law is more problematic. The 'Journalism' exemption to the Privacy Act 1988 at s. 7B(4) references privacy standards issued by the Australian Press Council as newspaper organisations' ticket to a waiver (APC, 2011). Media organisations simply have to avow they are 'publicly committed to observe standards' on privacy as documented by their representative organisation. However, the proposed reform would require more of them than simply being 'publicly committed to observe standards' and to have published them.

If they refused to sign up for the Convergence Review's 'self-regulator' they would have to follow in their journalism all of the privacy protocols applying to other corporations and marketers. Permissions would need to be sought and documented every time a citizen was named or identified visually in a news story or column and every time 'private' details about them and their lives were being published. It would be a logistical nightmare for a news organisation. There are already a myriad laws of defamation, trespass, data protection, surveillance, confidentiality, discrimination, consumer law, stalking, court publishing restrictions, suppression orders and copyright controlling the news media's handling of private information. The recommendation comes at a time the government is also considering a proposal for a 'statutory cause of action for a serious invasion of privacy' — giving citizens the right to sue over a privacy breach and receive either an award of damages or an injunction to stop publication. If the statutory tort were introduced, then the removal of the Privacy Act exemption for media companies would appear to be overkill given the array of other laws in the field. 


\section{Free expression implications of stronger regulation}

Reactions to the suggestion of a statutory regulator have certainly been strident and at times histrionic. Assistant to the Finkelstein inquiry, Professor Matthew Ricketson, responded in The Age to accusations that '... we would all be living in Stalinist Russia or even Hitler's Nazi Germany with its Reich Press Chamber if the government acted on this recommendation". He continued:

Really? What is actually recommended differs from the existing system in only one key aspect, namely government would fund the News Media Council. (Ricketson, 2012)

While he quite rightly took offence at such reactive rants, Ricketson was wrong to suggest that government funding of his proposed News Media Council was the only point of difference from the status quo.

Arms-length government funding of a self-regulator certainly sounds some alarm bells, but there may well be mechanisms to secure its independence, just as the $\mathrm{ABC}$ is publicly funded yet independent. The greater concern is with the body's ultimate power to refer disobedient media outlets to courts with the distinct possibility they might face fines or a jail term if they continued to disobey the council's order. Such powers place strong emphasis on the word 'enforced' in Finkelstein's system of 'enforced self-regulation' and pushes it a long way towards the full government regulation its critics fear. The proposal would effectively convert ethical codes into laws-ultimately enforceable in the courts.

This has certainly been a long overdue debate in Australia, but it has occurred in a politicised context that has been counter-productive and has undermined the likelihood of the implementation of any of the proposals. Several academics and small publishers stepped up to give the Finkelstein model their approval (The Conversation, 2012). Labor and Greens applauded it and pushed for its enactment, having demanded such an inquiry in the midst of the News Of The World scandal in the UK and continued adverse coverage about them in News Limited publications locally (Kitney et. al, 2012).

Criticism of the recommendations by the larger media groups on free expression grounds were dismissed as a defence of their vested interests. It surprised nobody that News Limited chief executive Kim Williams opposed statutory regulation (Meade and Canning, 2012), but such pigeon-holing of 
Finkelstein's serious critics is misplaced. History is littered with examples of politicians withdrawing citizens' rights to free expression because they did not like what they had been saying about them at a particular moment in time.

And, while the concerns of the Left at Murdoch media treatment might have helped trigger the inquiries, despite public protestations against the proposals by Opposition figures (Kerr, 2012), it is questionable whether a Conservative government would act to dismantle a new statutory regulator and its 'independence' could well be tested. The Howard conservative government lacked an impressive free expression record. It famously appointed arch conservatives to the 'independent' $\mathrm{ABC}$ board, ramped up anti-terror laws and cynically exploited exemptions to freedom of information requests. That government's foreign minister, Alexander Downer, confessed to newspaper publishers in 2006: 'Freedom of information always seems a great idea when you are in Opposition but less so when you are in Government' (McNicoll, 2006).

The Australian Press Council—with a suitable name change-could become an effective pan-media self-regulator and fulfil similar functions to the one proposed by the Convergence Review. That review's suggestion of encouraging membership with the carrot of consumer law exemptions is also a mechanism worth considering.

A uniform code of practice across all news media is a vital reform. It is essential that media outlets and journalists conform to ethical codes. It is in their interests that they do so, because it is these very ethical standards that distinguish them from the many new voices seeking audiences in the new media environment. But Australia has a confusing array of self-regulatory and co-regulatory documents guiding ethical standards of journalists and their outlets. No single journalist could possibly be expected to understand and operate effectively within deadline, paying heed to all that might apply to him or her, including the MEAA Code of Ethics, an in-house code, an industry code and the related laws and formal regulations that might apply.

This moots strongly for a single code of ethics applying to journalists and their employers across all media, similar to the existing MEAA Code of Ethics, addressing fundamental principles of truth, accuracy, verification, attribution, transparency, honesty, respect, equity, fairness, independence, originality and integrity, with exceptions only for matters of substantial legitimate public concern. Of course, this could be supplemented by industry or workplace 
'information and guidance' documents to help explain to journalists and editors the fact scenarios and precedents applying to a particular medium or specialty, along the lines of the Australian Press Council's guidance releases. As Ricketson (2012) has suggested, media outlets need to be more pro-active in developing better in-house processes for assessing ethical decisions and in explaining those decisions to their audiences. All reforms will, of course, need to be supplemented with better training of journalists about their rights and responsibilities and broader education of ordinary citizens to raise their level of media literacy.

Australia is rare among Western democracies in that it does not have free expression or media freedom enshrined in its Constitution and no federal bill of rights with such a protection. Other countries like the UK and New Zealand proposing similar regulatory mechanisms have free expression as an explicit right informing their jurisprudence. The closest Australia has come to any such protection came in a series of decisions through the 1990s, starting with the Australian Capital Television Pty Ltd v. Commonwealth and Nationwide News v. Wills cases in 1992, where the High Court introduced and developed a so-called 'implied freedom to communicate on matters of politics and government'. The court held this principle was fundamental to the system of representative government, but it demonstrated recently in Wotton v. Queensland (2011) that it was in no rush to progress this implied freedom. The Australian Capital Territory and Victoria have enacted limited charters of rights in the form of human rights acts, both of which enshrine free expression at the state and territory level, but neither applies to other jurisdictions and each is problematic even in its application in its own jurisdiction (Pearson \& Polden, 2011, pp. 38-39).

The lack of any formal written guarantee of a free media makes proposals for statutory regulators even more of a threat to democracy in Australia than in most comparable nations and this fact did not appear to weigh heavily enough with the architects of the Finkelstein report or those who rushed to support it. 'Enforced self-regulation' is not a suitable solution-at least not until free expression earns stronger protection from a more enthusiastic High Court or in a national bill of rights. Stronger self-regulation with the carrot of consumer law exemptions for compliant media outlets would strike the appropriate balance of freedoms and responsibilities in the interim. 


\section{References}

Applegarth, P. (2008). How deep is the media safe harbour? Gazette of Law and Journalism (QSC) [2008] QldJSchol 23. Retrieved on 16 September 2012, from http:// archive.sclqld.org.au/judgepub/2008/How\%20deep $\% 20$ is $\% 20$ the $\% 20$ safe $\% 20$ media\%20harbour.pdf

Australian Press Council (APC) (2011). Statement of privacy principles. Retrieved on 16 September 2012, from www.presscouncil.org.au/privacy-principles/

Christensen, N. (2011, October 31). Too many questions in six inquiries frustrate industry. The Australian [Media section]. Retrieved on 16 September 2012, from $\mathrm{http} / /$ theaustralian.newspaperdirect.com/epaper/viewer.aspx [Paywall]

Conroy, S. (2010, December 14). Convergence review. Terms of reference [media release]. Retrieved on 16 September 2012, from www.minister.dbcde.gov.au/ media/media_releases/2010/115

Convergence Review (2012). Convergence review. Final report. Canberra: Department of Broadband, Communications and the Digital Economy. Retrieved on 16 September 2012, from www.dbcde.gov.au/_data/assets/pdf_file/0007/147733/ Convergence Review Final Report.pdf

Conversation, The (2012 March 2). The Finkelstein inquiry into media regulation: experts respond. The Conversation. Retrieved on 16 September 2012, from: https:// theconversation.edu.au/the-finkelstein-inquiry-into-media-regulation-expertsrespond-5675

Day, M. (2012, April 9.) A shame Seven West should quit press council. The Australian. Retrieved on 16 September 2012, from www.theaustralian.com. $\mathrm{au} /$ business/opinion/a-shame-seven-west-should-quit-press-council/storye6frg9tf-1226321637864

Finkelstein, R. (2012). Report of the independent inquiry into the media and media regulation. Canberra: Department of Broadband, Communications and the Digital Economy. Retrieved on 16 September 2012, from www.dbcde.gov.au/_data/ assets/pdf_file/0006/146994/Report-of-the-Independent-Inquiry-into-the-Mediaand-Media-Regulation-web.pdf

Kerr, C. (2012, June 30). Libs reject Finkelstein proposal for media council, public interest test. The Australian. Retrieved on 16 Eptember 2012, from www.theaustralian.com.au/national-affairs/libs-reject-finkelstein-proposal-for-media-councilpublic-interest-test/story-fn59niix-1226413098639

Kitney, G., Massola, J. and Holgate, B. (2012, June 25). Media law push grows. Financial Review. Retrieved on 16 September 2012, from http://afr.com/p/national/ media law push grows gNdPHowMEqBOD35aQOm63O

McNicoll, D. D. (2006, 31 August). The diary. The Australian [Media section]. p. 18.

Meade, A. and Canning, S. (2012, March 3). Watchdog a threat to free press, claim news chiefs. The Australian. Retrieved on 16 September 2012, from www. theaustralian.com.au/media/watchdog-a-threat-to-free-press-claim-news-chiefs/ story-e6frg996-1226287785948 
Pearson, M. (2000). Advertorials and the Trade Practices Act: why the 'golden tonsils' saga might prove costly in the long run. Australian Journalism Review, 22(1), pp 57-67.

Pearson, M. and Polden, M. (2011). The journalist's guide to media law. Sydney: Allen \& Unwin.

Ricketson, M. (2012, May 26). Why I fear for the future of Australian journalism. The Age. Retrieved on 16 September 2012, from www.theage.com.au/opinion/societyand-culture/why-i-fear-for-the-future-of-australian-journalism-20120525-1za8x. html

Simpson, K. (2012, July 20). Journalism standards set for an updating. smh.com.au Retrieved on 16 September 2012, from www.smh.com.au/business/journalismstandards-set-for-an-updating-20120719-22czm.html

\section{Cases cited}

Australian Capital Television Pty Ltd v. Commonwealth (1992) 177 CLR 106. Retrieved on 16 September 2012, from: www.austlii.edu.au/cgi-bin/sinodisp/au/ cases/cth/HCA/1992/45.html

Australian Competition and Consumer Commission v. Channel Seven Brisbane Pty Limited [2009] HCA 19 (30 April 2009). Retrieved on 16 September 2012, from www.austlii.edu.au/cgi-bin/sinodisp/au/cases/cth/HCA/2009/19.html

Nationwide News v. Wills (1992) 177 CLR 1. Retrieved on 16 September 2012, from http://www.austlii.edu.au/cgi-bin/sinodisp/au/cases/cth/HCA/1992/46.html TCN Channel Nine Pty Ltd v Ilvariy Pty Ltd [2008] NSWCA 9. Retrieved on 16 September 2012, from www.austlii.edu.au/au/cases/cth/HCA/2012/2.html

Wotton v Queensland [2012] HCA 2 (29 February 2012). Retrieved on 16 Seeptember 2012 , from www.austlii.edu.au/au/cases/cth/HCA/2012/2.html

Dr Mark Pearson is professor of journalism at Bond University, Queensland, Australia; director of social media research for the Centre for Law, Governance and Public Policy; and co-author of The Journalist's Guide to Media Law (Allen \& Unwin, 2011). The author thanks Kiri ten Dolle for her research assistance and the reviewers for their suggestions. He blogs on media law at: journlaw.com

mpearson@bond.edu.au 
Copyright of Pacific Journalism Review is the property of Auckland University of Technology and its content may not be copied or emailed to multiple sites or posted to a listserv without the copyright holder's express written permission. However, users may print, download, or email articles for individual use.

http://www.aut.ac.nz/depts/commstud/journ/pjrsubs.shtml 